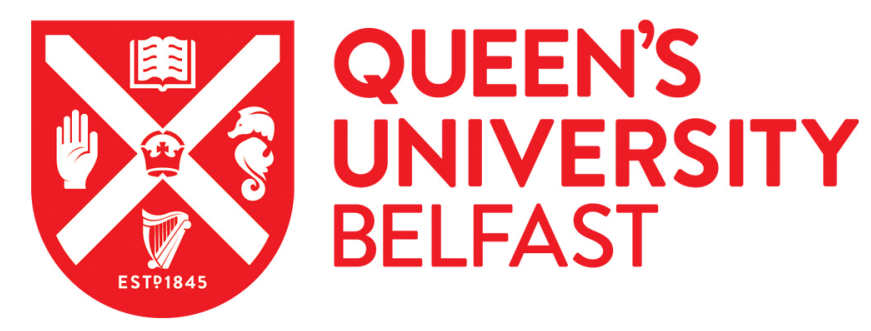

\title{
Incorporation of the United Nations Convention on the Rights of the Child in Law: A Comparative Review
}

Lundy, L., Kilkelly, U., \& Byrne, B. (2013). Incorporation of the United Nations Convention on the Rights of the Child in Law: A Comparative Review. International Journal of Children's Rights, 21(3), 442-463.

https://doi.org/10.1163/15718182-55680028

\section{Published in:}

International Journal of Children's Rights

\section{Document Version:}

Peer reviewed version

Queen's University Belfast - Research Portal:

Link to publication record in Queen's University Belfast Research Portal

Publisher rights

(c) Koninklijke Brill NV, Leiden, 2013.

\section{General rights}

Copyright for the publications made accessible via the Queen's University Belfast Research Portal is retained by the author(s) and / or other copyright owners and it is a condition of accessing these publications that users recognise and abide by the legal requirements associated with these rights.

Take down policy

The Research Portal is Queen's institutional repository that provides access to Queen's research output. Every effort has been made to ensure that content in the Research Portal does not infringe any person's rights, or applicable UK laws. If you discover content in the Research Portal that you believe breaches copyright or violates any law, please contact openaccess@qub.ac.uk. 


\title{
Incorporation of the United Nations Convention on the Rights of the Child in Law: A Comparative Review.
}

\author{
Laura Lundy, Ursula Kilkelly and Bronagh Byrne \\ In International Journal of Children's Rights, 21(3), 442-463. \\ INTRODUCTION
}

"The fate of human rights - their implementation, abridgement, protection, violation, enforcement, denial, or enjoyment - is largely a matter of national, not international, action" ${ }^{1}$

The fate of children's rights as a bespoke subset of human rights is, of course, the same: the translation of the promises of human rights law into reality for children is dependent not just simply or even mainly on international monitoring and review, but rather on the national actions of the governments who have ratified them. This was recognized from the outset in Article 4 of the United Nations Convention on the Rights of the Child ('CRC' or 'the Convention') which requires States Parties to: 'undertake all appropriate legislative, administrative, and other measures for the implementation of the rights recognized in the present Convention. With regard to economic, social and cultural rights, States Parties shall undertake such measures to the maximum extent of their available resources....' International human rights treaties do not, in general, specify how States Parties are to give effect to their obligations at the domestic level, but require them to take 'all appropriate measures' ${ }^{2}$ It is therefore up to states to determine how best to implement their international treaty obligations, subject to the satisfaction of those obligations in practice. The Committee on the Rights of the Child ('The Committee') has stated that each 'State party must decide for itself which means are the most appropriate under the circumstances with respect to each of the rights'. ${ }^{3}$ This article considers the ways in which a variety of countries have chosen to incorporate the CRC, drawing on a study conducted by the authors for UNICEF-UK. ${ }^{4}$ The purpose of the study was to identify the most effective and practical ways of giving effect to the Convention in law, drawing on experience in twelve purposively selected countries. The article begins with a review of the methods employed, followed by an examination of the various ways in which incorporation has occurred. These have been categorized into examples of direct incorporation (where the $\mathrm{CRC}$ forms part of domestic law) and indirect incorporation (where there are legal obligations which encourage its incorporation); and full incorporation (where the CRC has been wholly incorporated in law) and partial incorporation (where elements of the CRC have been incorporated). This is followed by an analysis of the impact of incorporation on the implementation of the CRC, drawing on evidence and interviews conducted on field visits in six of the countries under review. The article concludes with a discussion of the other nonlegal measures of implementation which emerged as key underpinnings for the success of legal measures of incorporation, followed by some reflections about what can be done to further support and facilitate a culture of respect for children's rights.

\footnotetext{
${ }^{1}$ Donnelly, J. Universal Human Rights in Theory and Practice ( $2^{\text {nd }}$ edition) London and Ithaca: Cornell University Press., p.171

${ }^{2}$ See for example Human Rights Committee, (1981) General Comment 3, Implementation at the National level at para 1. Geneva: UN.

${ }^{3}$ Committee on Economic, Social and Cultural Rights (1990) General Comment 3: The nature of states parties obligations, Geneva: UN, at para 4. See also Tobin, J. (2005) 'Increasingly seen and heard: the constitutional recognition of children's rights', S.Afr J on Human Rights, 21, p.89.

${ }^{4}$ Lundy, L, Kilkelly, U, Byrne, B and Kang, J (2012), The United Nations Convention on the Rights of the Child: A study of legal implementation in 12 countries, London: UNICEF-UK.
} 


\section{The UNICEF-UK Study}

The research team was commissioned by UNICEF UK to carry out a study of the legal implementation of the CRC in 12 countries. The overall purpose of the project was to research examples of incorporation of the Convention in countries beyond the UK in order to compile evidence of the most effective, practical and impactful ways of embedding children's rights into domestic law. The investigation was framed from a children's rights perspective and comprised of three key stages. First, a literature review was carried out with respect to the legal and non-legal implementation of human rights treaties generally, and the CRC specifically. The second stage of the project consisted of desk research on 12 countries identified by UNICEF-UK in conjunction with the research team and the Project and Advisory Boards. The countries were chosen to reflect a suitable mix of countries with: common and civil law structures, national and federated states, strengths in different aspects of the general measures of implementation, and varied child rights legislative models. The choice of countries was also influenced by their perceived degree of relevance to and relative influence on the UK. The 12 countries chosen for inclusion in the study were: Australia, Belgium, Canada, Denmark, Germany, Iceland, Ireland, New Zealand, Norway, South Africa, Spain, and Sweden.

To guide the development of each country report, the research team developed an analytical framework, allowing for the identification of: (i) the types of legislative measures adopted across jurisdictions; (ii) the characteristics of these measures; and (iii) the enablers and challenges in their development. Each country study drew on: States Party reports submitted by the identified countries to the Committee on the Rights of the Child; the Concluding Observations issued to these jurisdictions by the Committee; and relevant legislative and policy documentation pertaining to each country. While these documents provide a rich source of documentary evidence, we were aware of their limitations and in particular that the States Party reports and Concluding Observations provide a particular and partial representation of the position in each country at a specific point in time. ${ }^{5}$ To supplement these and to ensure that the most relevant and up to date information was captured in each country, draft versions of each country report were disseminated to international partners and contacts with UNICEF national committee offices, academics, government and NGO sector colleagues for feedback which was integrated into the country reports. This input was crucial to ensuring that the project team had a more accurate and nuanced understanding of the current reality in the state party under investigation.

Based on the data gathered, the research team selected a number of countries for in-depth analysis and review for the final stage of the project. Selection criteria were based on: (i) efficacy, that is, the apparent effectiveness and efficiency of the legislative model with respect to children's rights; and (ii) feasibility, that is, the appropriateness of the legislative model and implementation measures for the UK context. On the basis of these criteria, 5 countries were selected for field visits: Belgium, Germany, Ireland, Norway and Spain; and Australia for remote study In total, 58 interviews were carried out through the course of the study with representatives from: the relevant government department or agency with responsibility for children's rights; the Children's Commissioner/Ombudsperson, where established; leading academics and researchers; lawyers; children's sector organisations; service providers and practitioners; and those directly involved in the development and out-workings of the legislative model as appropriate. An additional objective of the interviews was to ascertain the impact, if any, of legal incorporation. While research was conducted into available childhood data sets (including international indices such as UNICEF scorecards, the PISA survey and WHO

\footnotetext{
${ }^{5}$ Prior, L. (2003) Using documents as social research, London: Sage.
} 
statistics), it was apparent from the outset that it was impossible to track chains of causation between legal implementation of the CRC and improved children's outcomes. However, it was possible in the interviews to investigate the perceived impacts of legal incorporation from the point of view of key stakeholders and to explore more generally whether and how these developments were instrumental in terms of building a culture of respect for children's rights.

\section{Approaches to Incorporation}

Implementation is the process whereby States Parties take action to ensure the realization of rights in the CRC for all children in a jurisdiction. ${ }^{6}$ Although implementation of the CRC is mandatory following ratification, the measures used to implement the Convention fall within each state's discretion. ${ }^{7}$ Incorporation - giving legal effect to the treaty in domestic law - is one means of implementing the CRC and although research indicates that those states in which the Convention has been incorporated - directly or indirectly, systematically or sectorally - are associated with a greater degree of implementation, the legal process of incorporation cannot be isolated from the range of measures that are necessary to implement the CRC successfully. Moreover, the way in which the CRC is given legal effect is highly contingent upon the constitutional and legal systems of individual countries. For example, in some countries (monist states), once the CRC is ratified, the Convention automatically becomes part of national law, whereas in others (dualist states), an act of parliament is required to transpose the Convention into the domestic legal order. Where the CRC is not automatically incorporated, only those provisions of the CRC that are expressly incorporated into national law will have legal effect. Other factors will determine the legal status of the Convention in national law after it has been incorporated, in particular where it sits in the hierarchy of the legal system. For example, in some jurisdictions, the CRC is equivalent to national statute law, whereas in others it will have constitutional status, superior to legislation. Separate again is the question of whether the Convention is justiciable and whether it can be used as a binding authority in the courts.

A study carried out by the UNICEF Innocenti Research Centre in 2007 noted that, at that time, the CRC had been directly incorporated into national law in two thirds of the 52 countries covered by the study. CRC provisions had been incorporated into the constitutional order of one third of the countries studied. ${ }^{8}$ Our study, carried out in 2012, found that full and direct incorporation of the Convention had taken place in just three countries of the 12 examined (Belgium, Norway and Spain), although a further four states had already or were in the process of incorporating some of the Convention's provisions into their constitutions in some form (Ireland, Iceland, South Africa and Sweden). However, we found it more common for states to incorporate specific Convention provisions into relevant legislation, rather than transposing the entire treaty into the national legal system. Those provisions most frequently incorporated on a sectoral basis were the best interests principle in Article 3 and the right to be heard in Article 12. The following section considers the different approaches adopted by the 12 states in our study towards incorporation of the CRC. It first considers examples of direct incorporation where the CRC in full or in part has been incorporated into the constitution or legislation. It then considers indirect incorporation (where other approaches are used to give the CRC legal effect in the domestic legal order).

\footnotetext{
6 Committee on the Rights of the Child, (2003), General Comment No. 5 (2003) Implementation UN/CRC/GC/2003/1, Geneva: United Nations.

${ }^{7}$ See Human Rights Committee, General Comment 3, Implementation at the National Level (1981) at para 1. See also Committee on Economic, Social and Cultural Rights (1990) General Comment 3: The Nature of States Parties Obligations, at para 4. See also Tobin, J. (2005) 'Increasingly seen and heard: the constitutional recognition of children's rights', S.Afr J on Human Rights, 21, p.89.

${ }^{8}$ UNICEF Innocenti Research Centre, (2007) Law Reform and Implementation of the CRC, Florence: UNICEF.
} 


\section{Direct Incorporation}

Direct incorporation is when the Convention, either in full or in part, is incorporated directly into the domestic legal system. This can happen either at constitutional level or at the level of statute, parliamentary instrument or act.

\section{Constitutional Incorporation - in full or in part}

Given that it is the most important instrument in the domestic legal order, incorporation of the Convention or specific CRC provisions into the national constitution must be seen as evidence of a commitment to recognition if not implementation of children's rights at the highest level. Tobin notes that greater attention has been accorded to the rights of children within constitutions adopted post $\mathrm{CRC}^{9}$ and recent years have seen an increasing trend towards enshrining children's rights in national constitutions. Of the 12 countries studied for UNICEF, six had taken or were taking steps to incorporate provisions of the CRC into their constitutions. Only Spain could be said to have incorporated the Convention into its constitution in its entirety, notwithstanding that this constitutional provision predates the CRC itself. In particular, Article 39(4) of the 1978 Constitution establishes that "[c]hildren shall enjoy the protection provided for in the international agreements safeguarding their rights". As a result, CRC provisions can be argued before the Constitutional and Supreme Courts. ${ }^{10}$ Although beyond this its effect is less clear, interviewees suggested that the constitutional commitment to children's rights created a symbolic 'red line' that could not be crossed. It also prompted full incorporation of the CRC into domestic law via the Organic Law on the Legal Protection of Children and Young People, adopted in $1996 .{ }^{11}$ It is also worth noting that, although the CRC is not fully incorporated into the Constitution in Belgium, its status - the CRC was automatically incorporated on ratification - is considered superior to both statute and the Constitution. ${ }^{12}$

A much more common approach among the countries studied was to incorporate select provisions of the CRC into their constitutions. This was identified in five additional countries Belgium, Ireland, South Africa and Sweden - with active consideration being given to this at the time of the study in Iceland ${ }^{13}$ and in Norway also. ${ }^{14}$ There was some consistency in the provisions selected for constitutional incorporation with the most common practice being to incorporate the best interest principle (under Article 3) and the right of the child to be heard (under Article 12). For instance, in 2000, these provisions were given explicit expression in Article 22bis of the Belgium Constitution along with Article 2 (non-discrimination principle) and protection for the moral, physical, psychological and sexual integrity of children. ${ }^{15}$ They are

\footnotetext{
${ }^{9}$ Tobin, J. supra note 3 .

${ }^{10}$ Spain's third and fourth state party report to the Committee details case law considered by these courts on constitutional matters affecting children's rights. Se CRC/C/ESP/3-4, 12 June 2010, para 78 with summary details of the judgments provided in Lundy, Kilkelly, Byrne and Kang, page 67.

11 Organic Law on Minors' Criminal Responsibility, 5/2000, available at http://noticias.juridicas.com/base_datos/Penal/lo5-2000.html, accessed $8^{\text {th }}$ April 2013.

${ }^{12}$ Belgium's Initial State Party report to the Committee on the Rights of the Child, CRC/C/11/Add.4, 6 September 1994, para 2.

${ }^{13}$ Iceland subsequently voted to adopt a new constitution,including provision for children's rights, on October $20^{\text {th }}$ 2012, See http://reut.rs/WB695x and http://bit.ly/XK5men, accessed 8 April 2013. The Convention on the Rights of the Child was incorporated into Icelandic law on 20 February 2013.

${ }^{14}$ In Norway, the Storting's Human Rights Commission recommended the inclusion of children's rights into the Norwegian constitution in 2011. See Human Rights Commission, Report to the Presidium of the Storting by the Human Rights Commission concerning human rights in the Constitution, 2011, p. 3, available at http://bit.ly/Xw2Rkp, accessed on 8 April 2013.

${ }^{15}$ Committee on the Rights of the Child, Concluding Observations: Belgium, CRC/C/15/Add.178, para 3.
} 
referenced in the recent change to the Irish Constitution also. ${ }^{16}$ Section $28(2)$ of the South African Bill of Rights stipulates that a child's best interests are of 'paramount importance in every matter concerning the child. Section 28 focusing mainly on children's socio-economic rights and explicit recognition is given to the child's right to a name and nationality from birth; family or alternative care, basic nutrition, shelter and health care and social services. It also recognises the right of the child to protection from maltreatment, neglect, abuse or degradation, from exploitative labour practices and recognises children's rights relating to detention and work. A further provision; Section 29 ,deals with the right to education. ${ }^{17}$ The South African Constitutional Court has handed down a number of significant judgments that have directly or indirectly affirmed children's rights. However, the Constitutional Court has yet to recognise Section 28 as giving rise to a directly enforceable immediate obligation against the state in any previous case. ${ }^{18}$ Sweden has also given constitutionalexpression to specific CRC provisions. In particular, Chapter 2 (Fundamental rights) of the Instrument of Government which forms part of the Constitution, contains two provisions which address the rights of children specifically: Article 7 contains a provision with respect to the determination of a child's nationality, and Article 18 stipulates that all children covered by compulsory schooling shall be entitled to a free basic education at a public school. In addition, as of January 2003, Article 2 of Chapter 1 (Basic principles of the form of Government), requires public institutions to combat discrimination on a number of grounds, including age. ${ }^{19}$ More importantly, perhaps, the Swedish Constitution was amended in 2010 and in particular, Article 2, Chapter 1 of the Instrument of Government now stipulates that "public institutions shall promote the opportunity for all to attain participation and equality in society and for the rights of the child to be safeguarded." (emphasis added) ${ }^{20}$ Ireland, whose 1937 Constitution already contained certain references to children within the context of the family (which enjoys very strong protection ${ }^{21}$ ), was amended to insert a new provision dealing with children's rights - Article 42A - into the Constitution in 2012. The first section of Article 42A contains an explicit statement that ' $[\mathrm{t}] \mathrm{he}$ State recognises and affirms the natural and imprescriptible rights of all children and shall, as far as practicable, by its laws protect and vindicate those rights. ${ }^{22}$ However, most of the remaining provision is limited to placing a duty on the parliament to enact legislation on children's rights (especially the best interests principle and the right to be heard), rather than giving these principles direct constitutional expression. This approach, of making legislative incorporation mandatory under the Constitution, has some hallmarks of the indirect model of incorporation (in that it stops short of incorporating substantive provisions into the Constitution).

Statutory Incorporation - in full or in part

\footnotetext{
${ }^{16}$ The full text of the wording can be found in the Thirty-First Amendment of the Constitution (Children) Bill 2012 http://bit.ly/10LPkIK, accessed on 8 April 2013.

${ }^{17}$ See Committee on the Rights of the Child, Concluding Observations: South Africa, CRC/C/15/Add.122, para 3. For the full text of the Charter see http://www.info.gov.za/documents/constitution, accessed 8 April 2013.

${ }^{18}$ See for example Constitutional Court of South Africa Minister for Welfare and Population Development $v$. Fitzpatrick and Others, BCLR 713 CC, 2000, paragraph 17.376; Constitutional Court of South Africa, Government of the Republic of South Africa v. Grootboom, BCLR 1169 (CC), 2001; Constitutional Court of South Africa, Minister of Health and Others v Treatment Action Campaign and Others, BCLR 1033 (CC), 2002.

${ }^{19}$ See Sweden's third State Party report, CRC/C/125/Add.1, para 249. 250, 251

${ }^{20}$ See the details at http://www.sweden.se, accessed 8 April 2013. Proposition 2009/10:80 entered into force on 1 January 2011.

${ }^{21}$ This is similar to the provision contained in the German constitution. See Lundy, Kilkelly, Byrne and Kang, $p$ 43. On the Irish Constitution, see further Kilkelly, U. and O'Mahony, C. (2007), 'The Proposed Children's Rights Amendment: Running to Stand Still?' Irish Journal of Family Law, vol. 2, p. 19.

22 See the Thirty-First Amendment of the Constitution (Children) Bill 2012 http://bit.ly/10LPkIK, accessed on 8 April 2013.
} 
All of the countries studied had, in one way or another, taken steps to incorporate the CRC either in full or in part into domestic legislation. Three states - Belgium, Norway and Spain have incorporated the Convention in its entirety into national law. In Belgium, this happened automatically by virtue of its ratification of the CRC. In Norway, this was a decision of the parliament taken in 2003, four years after the enactment of the Human Rights Act of 1999 which incorporated the International Covenant on Economic, Social and Cultural Rights (ICESCR), the International Covenant on Civil and Political Rights (ICCPR) and the European Convention of Human Rights (ECHR) into Norwegian law. It came following a recommendation of the CRC Committee. ${ }^{23}$ The CRC has formed part of Spain's domestic law since its ratification of the treaty in $1990 .{ }^{24}$ In both Australia (2011) and Denmark (2001), incorporation of the CRC was considered, but ultimately rejected. ${ }^{25}$

Almost all of the states examined in the UNICEF study could be found to have incorporated some of the CRC provisions into their sectoral laws on children's matters. Incorporation of the Article 3 best interest principle was found to be widespread. In all countries, it was found to be a fundamental principle in family law, ${ }^{26}$ and in some other countries it has been extended into areas like youth justice (e.g. Spain and Ireland ${ }^{27}$ ) and immigration and refugee law (e.g. Norway and Sweden). ${ }^{28}$ Many countries have also incorporated into statute the right of the child to be heard and/or to be represented. ${ }^{29}$ For example, this principle has strong protection in German law, with respect to children's participation in court proceedings, ${ }^{30}$ in Norwegian law, where children have strong participation rights in alternative care proceedings ${ }^{31}$ and in South Africa and Ireland, where it has underpinned the establishment of student councils in schools. ${ }^{32}$ To date, what is clear is that countries appear to have focused mainly on incorporating two main principles - Articles 3 and 12 - into their sectoral laws on children's matters, with some extension into other areas. There is little evidence of other CRC provisions being given statutory expression and Spain stands out as the only country, short of full incorporation, which has incorporated other substantive rights into a children's statute. In particular, the Spanish Organic Law from 1996 enshrines a number of civil rights for children including the right to freedom of thought, conscience and religion, the right to information, the right to freedom of assembly, the right to freedom of expression and the right to be heard

\footnotetext{
${ }^{23}$ See the Norwegian NGO Coalition on the CRC, Supplementary report to the UN Committee on the Rights of the Child, 1999; UN Committee on the Rights of the Child, Concluding Observations: Norway, CRC/C/15/Add.126, 2000a.

${ }^{24}$ Spain. Second State Party report to the Committee on the Rights of the Child, CRC/C/70/Add.9, 12 November 2001, paras 170-171.

${ }^{25}$ See Denmark, Third State Party report to the UN Committee on the Rights of the Child, CRC/C/129/Add.3, 2005, para 16. In relation to Australia, see the details of the review and the action plan that resulted at http://bit.ly/16HbCdL, last accessed 8 April 2013.

${ }^{26}$ For example, see the Commonwealth Family Law Act 1975 (Australia); the Children's Act 2005 (Norway); the Act on Parental Responsibility, 2007 (Denmark); the Care of Children Act 2004 (New Zealand) and the Children Act 1989 (England and Wales).

27 See the Children Act 2001, as amended (Ireland); and Organic Law No. 5/2000, Organic Law on Minors' Criminal Responsibility (Spain). See also the ACT Children and Young People Act 2008 (Australia).

${ }^{28}$ See the Immigration Act 2008 (Norway) and the Aliens Act 2005 (Sweden). See also the Borders, Citizenship and Immigration Act 2009 (United Kingdom) and case-law of the Canadian Supreme Court in Baker v. Canada (Minister of Citizenship and Immigration), 2 SCR 817, 1999 (Canada).

${ }^{29}$ See for example, the Children's Act 2005 and the Kindergarten Act, 2005 (Norway); the Organic Law on the Legal Protection of Children and Young People, 1996 (Spain) and the Adoption Act 2010 (Ireland).

${ }^{30}$ See the Act on Proceedings in Family Cases and in Matters of Non-contentious Litigation (Germany).

${ }^{31}$ On implementation of the 2005 Act see Skjørten, K., Samlivsbrudd og barnefordeling, Gyldendal Akademisk, Oslo, 2005; cited in Skjørten, K. And Barlindhaug, R., 'The involvement of children in decisions about shared residence', International Journal of Law, Policy and the Family, vol. 21, 2007, pp. 373-385. See also the Victoria Children, Youth and Families Act 2005 (Australia).

${ }^{32}$ See the Education Act 1998 (Ireland) and the South African Schools Act 84 of 1996 (South Africa).
} 
within the family and in administrative and judicial proceedings. In addition, the Law addresses the rights of children at risk or in need of protection, and regulates adoption procedures. Furthermore, Spain's Organic Law on Minors' Criminal Responsibility from 2000 outlines Spain's juvenile justice procedures and regulations and gives primacy to the best interests principle.

\section{Indirect Incorporation}

In addition to those states which have taken measures to incorporate CRC provisions directly into either national laws at the level of either statute or constitution, some states have taken measures which can be described as indirect incorporation. In effect, these measures are aimed to give the CRC some effect in national law but they stop short of making substantive rights part of the domestic legal order. The most significant of these measures can be found in Wales, which in March 2011 adopted the Rights of Children and Young Persons (Wales) Measure. The Measure requires Ministers of the Wales Assembly to have due regard to the requirements of the $\mathrm{CRC}$ and its Optional Protocols when making decisions about a provision to be included in an enactment, the formulation of a new policy and/or legislation, or a review of or change to an existing policy and/or legislation. ${ }^{33}$ The result of the Measure is not to incorporate the $\mathrm{CRC}$ directly into national law therefore but rather to require decision-making to take account of the requirements of the CRC. Scotland is also in the process of introducing similar legislation. The Children and Young People Bill (Scotland) was introduced to Parliament on 17 April 2013 and will place a duty on Scottish Ministers keep under consideration whether there are any steps which they could take which would or might secure better or further effect in Scotland of the CRC requirements, and to take identified steps if deemed appropriate. . ${ }^{34}$ It is accompanied by a duty to raise awareness and understanding of the rights of children and young people. This measure builds on the measures introduced in some countries designed to require law making to take account of children's rights obligations. For instance, in the Flanders Region of Belgium, every draft decree that impacts on the interest of young people under 25 years must be accompanied by an impact assessment. Although an evaluation has questioned the efficacy of the measure (known as its acronym 'Joker') ${ }^{35}$, it is likely to be introduced in the French speaking Region in the near future. ${ }^{36}$ Australia has also taken such a route, with the enactment in $\mathbf{2 0 1 1}$ of the Human Rights (Parliamentary Scrutiny) Act. This introduces a requirement for statements of compatibility to accompany all new bills, which must contain an assessment of whether the bill or legislative instrument is compatible with the seven core international human rights treaties that Australia has ratified, including the $\mathrm{CRC}$. The procedure is new and there is as yet no published example of change occurring as a result of a perceived incompatibility with the CRC. ${ }^{37}$

In summary then, there is considerable evidence of the incorporation of the CRC into the national law of the countries studied. Incorporation of the two main CRC principles - best interests and the right to be heard - is now widespread in family law and some countries have

\footnotetext{
33 See Rights of Children and Young Persons (Wales) Measure (2011), available at http://www.legislation.gov.uk/mwa/2011/2/contents, last accessed 3 May 2013. See further Williams, J. 'General legislative measures of implementation: individual claims, 'public officer's law' and a case study on the UNCRC in Wales', International Journal of Children's Rights, vol. 20, 2012, pp. 224-240, p. 226; Williams, J. (2013) The United Nations Convention on the Rights of the Child in Wales, University of Wales Press: Cardiff. ${ }^{34}$ Children and Young People (Scotland) Bill, available at http://www.scottish.parliament.uk/parliamentarybusiness/Bills/62233.aspx, last accessed 3 May 2013.

${ }^{35}$ See Desmet, E., Op de Beeck, H. And Vandenhole, W, Evaluation of the Child and Youth Impact Assessment (JoKER), Kenniscentrum Kinderrechten, Gent, 2012.

${ }^{36}$ Belgium, Third and fourth State Party reports to the UN Committee on the Rights of the Child, $\mathrm{CRC} / \mathrm{C} / \mathrm{BEL} / 3-$ 4, 2010.

${ }^{37}$ However, interviewees commented on its potential for positive effect. See Lundy, Kilkelly, Byrne and Kang, pp 30-31.
} 
extended the principles to other laws affecting children. Several countries have taken steps to give constitutional expression to children's rights and others are considering or have considered this step. The result is that all countries studied here can be said to have incorporated the CRC directly in full or in part into national law whether at statutory or constitutional level. Finally, a number of countries have adopted measures designed to ensure that the CRC is taken into account in law and policy making. However, whatever the impact of these measures (explored below), it is clear that no single measure will achieve change on its own.

\section{The Impact of Incorporation}

The review of comparative practice in relation to the implementation of the CRC in the 12 countries included in this study indicates that: each of the countries in the study is taking the implementation of the CRC seriously, albeit in various ways and with varying degrees of commitment. The legal and policy responses to implementation by necessity vary on a country by country basis and are determined to a large extent by its legal and administrative structures as well as political and public attitudes to international human rights law in general and children's rights in particular. While recognising that these are often the determining factors, there were some overarching messages which can be drawn from across the country studies about the impact of systematic approaches to incorporation.

In the countries where there had been specific, high-level incorporation of the CRC, interviewees were more likely to say that children were perceived as rights-holders and that there was a culture of respect for children's rights. It remains unclear whether this enhanced respect for children's rights explains why there had been more systematic incorporation to begin with or was in fact a by-product of it. In some countries, interviewees reported a general culture of respect for rights (Norway, Belgium), while others suggested that one had developed in the wake of conflict and significant reconstruction (Spain, South Africa). In others, human and child rights were not considered to be the normal discourse with values such as childcentredness or equity having more purchase (Australia). In several countries, child protection or 'the child as victim' were reported as being more common public attitudes (e.g. Ireland, Germany) and, in several instances, the tension between parents' rights and children's rights appeared to be part of the ongoing discussion, with adverse impact for the acceptance of children's rights (Australia, Germany, Ireland). While it was suggested that a deliberate decision to incorporate (as in Norway) might have more impact than instances where the CRC has automatically become part of domestic law upon ratification (Belgium, Spain), this is difficult to determine. Nonetheless, the process of discussion and consultation around incorporation was recognised as having a positive role in advancing understanding and engaging with key stakeholders (e.g. with young people in Iceland), even where the outcome of that did not result in incorporation (as in Australia). Where it had taken place, incorporation clearly provided the springboard or basis from which a range of other measures and initiatives to implement the Convention were either launched or flowed naturally as a consequence.

One of the reported consequences of incorporation at a high level (for instance, in the constitution or through an act of general implementation) was that CRC principles appeared to be more likely to be translated into domestic law. It was reported variously that it gave politicians, public officials and NGOs who wanted to advance the cause of children's rights a "hook" or "leverage" which was particularly influential when it came to ensuring integration of the principles in domestic law and policy. So, for example, the adoption of the CRC in the Spanish Constitution paved the way for the two key Organic Laws covering a comprehensive range of CRC rights, including civil and political rights. ${ }^{38}$ Likewise, in Norway (and Sweden), there appears to be a more systematic approach to incorporation of CRC articles, whereas in other countries (such as Australia, Germany and indeed the UK), sectoral incorporation was 
the norm and was more likely to be confined to the area of family law and to Articles 3 and 12 in particular. While the latter is important, it falls somewhat short of full implementation of the CRC as required by Article 4.

Incorporation also provided opportunities for the CRC to be used in litigation. There were examples of strategic cases being taken in all of the countries studied, with key successes notable in countries where it has been incorporated in such a way as to allow for direct enforcement. So, for example, in Norway a recent Supreme Court decision had insert examples of cases\}. However, it was equally clear that incorporation had not opened a floodgate of strategic litigation involving children. Instead, the impact of incorporation was that key principles of the CRC more likely to be cited in more routine cases involving children (and was in fact perceived as a normal part of the legal discussion in court cases in countries such as Belgium or Sweden).

In all countries in the study, the most vulnerable groups of children (separated children, asylum seekers, indigenous children and children in conflict with the law) continued to fare less well compared to their peers, irrespective of the steps taken to incorporate the CRC. Throughout the interviews this was linked to higher levels of poverty and social exclusion. In several countries (including Spain and Germany), interviewees suggested that separated children and asylum seekers were not seen as rights holders in the same way as other children and this was linked, to an extent, to the weakness of the CRC in these areas. For this reason perhaps, some of the most effective forms of redress were perceived to lie in constitutional or domestic equality protections rather than specific child rights arguments although it is clear that a variety of strategies were important in addressing these intractable issues. Interviewees also highlighted their concerns about the impact of the recession on children's rights, albeit that some suggested that a benefit of incorporation of the CRC was that it provided a line over which government could not step in relation to the introduction of austerity measures.

Finally, a recurring theme in relation to impact of incorporation in law was the fact that the measures adopted were not consistent across different regions within one States Party, even where there had been significant steps taken to incorporate the CRC at a high level. In many of the case study countries, the state party ratified the CRC but key responsibility for ensuring its implementation in law, policy and practice rested with devolved or federated regions which had significant responsibility for areas such as education, health and social care (Australia, Belgium, Germany, Spain). Decentralization of power, through devolution and delegation of government, does not reduce the direct responsibility of the State Party's Government to fulfil its obligations to all children within its jurisdiction, regardless of the State structure. ${ }^{39}$ However, it was clear that some of the responsibility on the State Party to ensure implementation of the CRC was diluted in the transfer of responsibility, with the central government limiting its role sometimes to monitoring and compiling the periodic report. Many interviewees suggested that central government should explicitly retain overall responsibility for implementation of the CRC and take a more active role in ensuring that local regions/ states are actively and consistently implementing the Convention. It was suggested that this would work best through national mechanisms to co-ordinate activity which would develop national agreements on key issues which cross regional boundaries (e.g. Australia has a system of co-operative agreements, known as 'Co-Ags' which have enabled government departments to collaborate to produce national level agreements on issues such as child care standards). Others suggested that greater consistency could be encouraged further by targeted national funding for particular policies and by having greater consistency in data collection.

\footnotetext{
${ }^{39}$ Supra n. 6 . The Committee has reiterated that in any process of devolution, States parties have to make sure that the devolved authorities have the necessary 'financial, human and other resources effectively to discharge responsibilities for the implementation of the Convention'.
} 


\section{Non-Legal Measures of Implementation in Support of Incorporation.}

The Committee on the Rights of the Child has made clear throughout its General Comments, and General Comment 5 in particular, that effective implementation of the CRC is not achieved by legislative measures alone. It has identified a range of non-legal measures that are needed for effective implementation, including the development of particular structures, training and awareness and other activities. ${ }^{40}$ The research looked at all of these in the contexts of the countries studied. It was clear that a range of approaches was being adopted to support implementation of the CRC, including the development of national plans for children, data collection across children's lives, child participation in decision-making processes at governmental and/or local authority levels, and child budgeting. ${ }^{41}$ However, for the purposes of this paper, four in particular emerged as core to the success of any legal strategy to implement the CRC: training and awareness, the role of independent human rights institutions, data and national action plans.

\section{Training and awareness}

The State has a duty under the CRC to develop training and capacity-building for all those involved in the process of implementing Convention rights and for all those working with and for children. ${ }^{42}$ This should be systematic, ongoing, and integrated into all professional training codes and educational curricula. ${ }^{43}$ The significance of awareness-raising is grounded in Article 42 of the CRC which obliges States Parties to make its principles and provisions widely known. In spite of the emphasis in the CRC on children being informed about their rights, research has highlighted the continuing lack of accurate knowledge and awareness of children's rights. ${ }^{44}$ The need for training and awareness on the CRC itself was reiterated time and time again by interviewees in the study who recognised that, at every level, from legislation to case law and policy development to service provision for children, effective implementation was contingent upon awareness of children's rights. This was not just about knowledge of the articles of the Convention or about children's issues like child protection, but an understanding of children as the subject of rights - entitled to be treated with dignity and respect and to exert influence on their own lives. For example, while the best interest principle has been widely incorporated in legislation, awareness of the CRC was perceived to be crucial to ensuring it was applied in a way that was rights compliant. In spite of this, and the Committee's recommendation that States develop a comprehensive strategy for disseminating knowledge of the $\mathrm{CRC},{ }^{45}$ there were few examples of systematic training for duty bearers. Examples of good practice include legal training for the legal profession and judiciary in Norway and Belgium which has led to an increased number of cases where the CRC is cited, ${ }^{46}$ while in Australia, human rights education targeted at schools, communities, public servants and those working with children, is one of the core principles of its recent Human Rights Framework. ${ }^{47}$

\footnotetext{
40 United Nations (2003) Committee on the Rights of the Child, General Comment No. 5, General Measures of Implementation for the Convention on the Rights of the Child, UN/CRC/GC/2003/5, Geneva: United Nations.

${ }^{41}$ See Lundy, Kilkelly, Byrne and Kang (2012).

42 United Nations (2003) General Comment No.5.at para 48.

43 United Nations (2003) General Comment No.5, at para 53.

${ }^{44}$ See for example, Alderson $P$ (1999) Civil rights in schools: The implications for youth policy. Youth and Policy 64: 56-72; Covell, K. \& Howe, B. (1999). The impact of children's rights education: A Canadian Study. International Journal of Children's Rights 7(2):171-183; Howe, R. B., \& Covell, K. (2005). Empowering Children: Children's Rights Education as a Pathway to Citizenship. Toronto: University of Toronto Press

45 United Nations (2003) General Comment No.5 at para 33.

${ }^{46}$ Lundy, Kilkelly, Byrne and Kang (2012), p.39 and 61.

${ }^{47}$ Human Rights Branch (2010) Australia's Human Rights Framework, Attorney-General's

Department: Commonwealth of Australia.
} 
While there was widespread recognition in the study of the need to educate adults working with children and to increase sensitivity among the public, few interviewees, with Norway being an exception, identified education for children about the UNCRC as important in the implementation strategy: it was seen as something that the CRC requires as a substantive right rather than as a means of implementation. There was very little focus on the ideas of building children's capacity to claim their rights now. However, some interviewees recognised that children's rights education would change culture over generations as children become future duty bearers. Most countries had included aspects of human rights and child rights in the general curriculum, although these were rarely extensive and often optional elements. There were, however, interesting examples of child rights education in most jurisdictions. In Nova Scotia, Canada, for example, child rights education has been integrated into schools as part of the health and social studies curriculum from kindergarten up to Grade $6,{ }^{48}$ while in Denmark, the CRC forms part of human rights education more generally. ${ }^{49}$ Whilst the need to include education about the Convention in national curricula has been emphasised by the Committee on the Rights of the Child, ${ }^{50}$ in practice this was not evident in the countries studied, with much of this work being undertaken by NGOs.

\section{Independent National Human Rights Institutions}

Independent national human rights institutions (NHRIs) have been identified as an important mechanism to promote and ensure the implementation of the CRC and the Committee has welcomed the establishment of children's ombudspersons/children's commissioners to this end. ${ }^{51}$ In order to ensure their independence and effective functioning, the Committee has highlighted that children's commissioners must have adequate infrastructure, funding (including specifically for children's rights, within broad-based institutions), staff, premises, and freedom from forms of financial control that might affect their independence. They must have the power to consider individual complaints and petitions and carry out investigations, including those submitted on behalf of or directly by children, ${ }^{52}$ and to support children taking cases to court. ${ }^{53}$ Not all national children's rights institutions are obliged to monitor the CRC and much will depend upon the establishing legislation. Most of the countries in the study had a children's commissioner or ombudsman. Australia was a late exception, having only recently decided to appoint a national children's commissioner, ${ }^{54}$ although there were children's commissioner offices in each of the states. ${ }^{55}$ The absence of a Commissioner or Ombudsperson at federal level was also the case in Canada; however a number of Provinces had established Child and Youth Advocates in addition to the Youth Services Section of the Nova Scotia Office of the Ombudsman and the Québec Commission des droits de la personne et des droits de la jeunesse. Not all countries had independent monitoring mechanisms; in

\footnotetext{
48 Canada's Second State Party Report to the United Nations Committee on the Rights of the Child (2003), CRC/C/83/Add.6, para 1338.

49 Denmark Fourth State Party Report to the United Nations Committee on the Rights of the Child (2010), CRC/C/DNK/4, para 31.

50 United Nations (2003) General Comment No.5, at para 18.

51 United Nations (2002) General Comment No.2: The role of independent national human rights institutions in the promotion and protection of the rights of the child, Geneva: UN, CRC/GC/2002/2 at para 1.

52 United Nations (2002) General Comment No.2 at para 6.

53 United Nations (2002) General Comment No.2, at para 25.

54 The first National Children's Commissioner for Australia took up post on 25 March 2013.

55 For a summary of the remit and powers of state-based children's commissioners, see Australian Institute of Family Studies, 'Children's commissioners and guardians', 2011, http://www.aifs.gov.au/nch/pubs/sheets/rs15/ last accessed 27 March 2013.
} 
Germany for example, the Children's Commission at federal level is a subcommittee of the parliamentary Committee for Family Affairs, Senior Citizens, Women and Youth. ${ }^{56}$

A 2011 study by Save the Children of the general measures of implementation across five countries in Europe found that mandates and roles differed between children's commissioners/ombudspersons. ${ }^{57}$ Similarly, the bodies examined in this study had very different powers and resources, often not as extensive as those invested in the four UK children's commissioners. However, where an Ombudsman approach had been adopted, as in Spain and Ireland, it was considered that the ability for children to make complaints directly to the office for investigation played an important role in the enforcement of the CRC. The Commissioners/Ombudsman offices were perceived to be core to monitoring implementation across time, to holding government to account and to ensuring consistency in the implementation of the CRC at times of political change. They also have a key awareness raising role. The extent to which the commissioners or ombudsman's offices were able to fully realise their mandate was often hampered by the limited resources available. Practice and resourcing also varied considerably across States within federal jurisdictions. ${ }^{58}$

\section{National Plans for Children}

Almost all of the countries in the study had a national plan for children. ${ }^{59}$ The effective protection of children's rights through a unifying, comprehensive and rights based national strategy rooted in the Convention has been strongly emphasised by the Committee. ${ }^{60}$ Where such plans have been in place, these have taken different forms and varied in their content, goals and implementation structures. In some instances plans have not always been renewed at the end of their timespan; Germany's National Action Plan for a Child Friendly Germany, for example, ended in 2010 while Spain's National Strategic Plan for Children and Adolescents finished in 2009 with its successor still under discussion. Interviewees suggested that for these to be most effective, there needed to be concrete action plans supported by measurable targets and indicators, and appropriate resourcing - core factors which have been reiterated by the Committee in its General Comment. ${ }^{61}$ In rare instances national plans were linked to CRC implementation as in the Flemish Community in Belgium ${ }^{62}$ and in Canada. ${ }^{63}$ Yet, even where this was not the case, it is clear that an ambitious national strategy can drive implementation of the Convention in particular areas. Ireland's National Children's Strategy $2000-2010$ is a key example of a plan where the inclusion of participation as a key policy goal has led to a whole range of innovative and ambitious participation initiatives, including the development of structures for children to feed into local decision-making. Where national plans are used to establish infrastructure and to embed children's rights into administrative decisionmaking, they can have a clear impact on children's rights awareness and implementation.

\footnotetext{
${ }^{56}$ Germany's Second State Party Report to the United Nations Committee on the Rights of the Child (2003),CRC/C/83/Add.7, at para 15.

57 Save the Children (2011) Governance Fit for Children: To what extent have the general measures of implementation of the UNCRC been realised in five European Countries? Stockholm: Save the Children.

${ }^{58}$ Interviewees indicated that these offices were under threat due to cuts in public sector spending.

${ }^{59}$ Australia's National Human Rights Action Plan considers the CRC along with the other six core treaties but is not specific to children. The Australian Research Alliance for Children and Youth are in the process of developing a national plan for children's well-being. See http://www.thenestproject.org.au/ last accessed 27 March 2013. However, this is not a government initiative.

60 United Nations (2003) General Comment 5, at para 28

61 United Nations (2003) General Comment 5, at para 32.

${ }^{62}$ Flemish Action Plan for the Rights of the Child, 2004. This was subsequently incorporated into the Belgian National Action Plan for Children (2005-2012).

${ }^{63}$ A Canada Fit for Children (2004).
} 


\section{Comprehensive data on children}

Sufficient and reliable data collection on children, disaggregated to enable identification of discrimination and disparities in the realisation of rights is an essential part of implementation of the Convention. ${ }^{64}$ An annual comprehensive report on the state of children's rights in the jurisdiction is recommended by the Committee on the Rights of the Child. ${ }^{65}$ The collection of good quality data on children's lives is particularly important in facilitating an examination of the disparity between "the de jure protection and de facto realization of human rights" 66 and helping to identify and explain the causes and variation in the failure to implement children's rights. ${ }^{67}$ There was general agreement among interviewees that children's rights implementation is underpinned by comprehensive data; that this needed to be collected systematically in a way that identifies the most vulnerable categories of children; and that change needed to be tracked over time. Several countries, such as Spain ${ }^{68}$ and Germany ${ }^{69}$, publish official annual state of children's rights reports and these were identified as useful. Some have invested quite considerably in data collection; Ireland for example has developed a national longitudinal study called Growing up in Ireland ${ }^{70}$ which is producing a wealth of qualitative and quantitative information about children's lives and a clear evidence base for policymakers. Elsewhere, the Australian Early Development Index ${ }^{71}$ will track children across time and includes specific data collection for vulnerable groups, including indigenous children. However, in most instances, the focus was on key child development and well-being indicators rather than the full range of children's rights. Attempts to develop and employ child rights indicators remain rare. $^{72}$ Across the studies, interviewees highlighted that without comprehensive, consistent, up to date, disaggregated data it was very difficult to understand or track the impact of government policy on children. Interviewees also referred to the need for effective ways of evaluating whether government policy on children's issues was having its desired effects.

\section{Conclusion}

The UNICEF-UK study provides a wealth of information on the various measures, legal and non-legal, taken by the countries studied to advance implementation of the CRC into domestic law, policy and practice. It identifies many of the factors that serve to promote children's rights at national level and highlights those strategies that have been proven to be most effective in both implementing the CRC in law and policy and in persuading decision-makers and duty bearers about the importance and value of implementing the CRC at national level. Where possible, the effectiveness of those approaches was clarified although it remains difficult to

\footnotetext{
64 United Nations (2003) General Comment 5, at para 48.

65 United Nations (2003) General Comment 5, at para 29.

${ }^{66}$ Landman, T. (2005) Protecting Human Rights: A Comparative Study, Washington D.C: Georgetown University Press, p.5.

${ }^{67}$ Carvalho, E. (2008) Measuring Children's Rights: An Alternative Approach, International Journal of Children's Rights, 16, pp.545-563, p.545.

${ }^{68}$ Government of Spain (2011) Childhood in Figures 2009, Universidad Complutense Madrid, Madrid, http://bit.ly/UEltsy, last accessed 27 March 2013.

${ }^{69}$ Book VII of the Social Code (Child and Youth Services) (Section 8(1)) (1990) places an obligation on the Federal Government, the Bundestag and the Bundescrat to report on the situation of, and developments relating to, children during each legislative period.

${ }^{70}$ Growing up in Ireland National Longitudinal Study of Children, see http://www.growingup.ie/ last accessed 27 March 2013.

${ }^{71}$ Australian Early Development Index, see http://ww2.rch.org.au/aedi/index.cfm?doc id=13051 last accessed 27 March 2013.

${ }^{72}$ South African Human Rights Commission/UNICEF South Africa (2011) South Africa's Children - A Review of Equity and Child Rights, http://bit.ly/MmB1MR last accessed 27 March 2013. See generally, Lundy, L (2013 forthcoming), The
} 
establish in any definitive or scientific way the actual impact on children's lives of the approaches and measures taken. Nevertheless, what emerges from the research is an understanding that children's rights are better protected - at least in law if not also in practice -in countries which have given legal status to the CRC in a systematic way and which have followed this up by establishing the necessary systems to effectively support, monitor and enforce the implementation of CRC rights. Equally, it is clear that each country must find its own path towards full implementation: there is no single route to be taken, no one right way to proceed. While the aim of the research was to identify some of the most effective approaches adopted, what also emerged were some interesting findings, primarily drawn from the stakeholder interviews, on the people, processes and contexts which made these legal changes possible.

Across the country studies, there was evidence of significant advocacy work by NGOs, who were often targeting legal and constitutional reform and regularly took the lead in the shadow/alternative reporting process to the UN Committee on the Rights of the Child. While it is impossible to identify all of the NGOs active in this area, impressive advocacy work was being carried out by, inter alia, the UNICEF NatComs and a number of high profile coordinating organisations such as the Platforma di Infancia in Spain. This appeared to be most effective when it employed a combination of strategies such as the engagement of the public and media on the issue, the pursuit of a strategic legal approach and persistent lobbying, based on the CRC, of Government and decision-making bodies. In terms of the latter, it was seen to be important to have key advocates or supporters in Government or in public office. In many countries, the most significant changes in relation to implementation of the CRC can be traced to their support by a particular champion - a politician, a key government official, an experienced law professor or an NGO leader - with influence. Interviewees identified a number of such champions working in different areas, including constitutional change, policy reform and participatory practices (e.g. Belgium, Germany, Norway, Ireland). NGOs were conscious of the need to identify and support such champions as part of their advocacy and lobbying strategies. However, while change often stems from a particular political champion, there was a recognized danger that reliance on such individuals meant that support for the CRC could ebb and flow. This is especially the case when the individual is in a political party which has lost power as the issue can be seen as being identified with that party. On the other hand, when the champion is a public official, there can be continuity and an opportunity to build support and ensure consistency over time. Reliance on key individuals to drive implementation also makes it difficult to sustain progress if the culture and the infrastructure to support it have not been sufficiently established.

An additional driver towards implementation was the effect of peer pressure effect from pioneering developments within individual regions in the jurisdiction. Thus, while there is ongoing concern about inconsistency in approaches across regions, one of the advantages of devolved power in federated systems was that it often enabled one region or jurisdiction to lead, prompting others to follow, unconstrained by limitations existing at federal or national level. In each country, certain areas or regions were identified as being at the forefront of the implementation of the CRC (such as Victoria in Australia, Catalonia in Spain, Berlin in Germany and, in different respects, the Flemish and French Communities in Belgium) and it was suggested that these regions played an important role in encouraging good practice elsewhere. The finding is of particular interest in the UK as the devolved administrations of Wales and Scotland have recently adopted novel approaches to CRC incorporation. Goodman and Jinks suggest that recalcitrant actors can be encouraged to implement human rights obligations through one or more of three processes - coercion, persuasion and/or acculturation. ${ }^{73}$ Thus, when one region steps forward in terms of legal incorporation, much

73 Goodman R. \& Jinks, D. (2004) How to influence states: socialisation and international human rights law, Duke Law Journal 54(3) 621-702. 
may be achieved in terms of convincing others (persuasion) or at least prompting the feeling that their peers ought to be doing or be seen to be doing more than they are (acculturation).

Finally, the CRC reporting process was also identified as an important element of building a culture of respect for rights and an opportunity to advocate for increased incorporation of the CRC in law. Many of the interviewees had been involved in reporting to the Committee either as a government representative or as part of the alternative reporting process. It was clear that constructive engagement in the reporting process can be a driver to greater implementation, with several government interviewees reporting a greater level of awareness and personal commitment to the CRC in the wake of their experience and others pointing to the potential of the reporting process to engage the public and the media on children's rights issues. It was suggested that the reporting process opened discussion around the legal incorporation of children's rights within the states party and encouraged dialogue and discussion between duty-bearers and key stake-holders.

In summary, it is clear that in many countries the systematic incorporation of the CRC into domestic law provided a platform from which other legal and non-legal measures developed. Although it is possible to argue that incorporation was not indispensable to the measures that followed (i.e. that measures short of incorporation might achieve the same results), the research shows that it is an important goal in itself to give the CRC the force of national law. In particular, both the process of incorporation - which raises awareness and can be accompanied by systematic training of decision-makers - and the result - where the CRC becomes internalised in the national level system - have significant value in 'bringing rights home' to children and to duty-bearers. As the research shows, positive consequences flow from this- in the form of how children's rights are perceived and implemented in practice that would be difficult to achieve through other means. Related to this is the impact that systematic incorporation can have on the content of domestic law and policy and, as those who are governed by the national law and policy framework - state officials and decisionmakers - work with the national law, the CRC starts to infuse the decisions they make and how they are made. Of course, all of this must be underpinned by systematic children's rights training and a robust infrastructure designed to monitor, support and enforce implementation, if its potential is to be fully realised. Here several stakeholders - UNICEF, national human rights institutions, NGOs, academics and the media for example - have key roles. The work that they undertake - as watchdogs observing and documenting progress, auditing compliance, holding government to account, lobbying for change and engaging and raising the awareness of the public - is essential in ensuring that progress towards full implementation is sustained. 